\title{
APPLICATION OF THE METHOD OF INQUIRY TO IMPROVE THE ACTIVITY AND STUDENT LEARNING OUTCOMES IN CUBES AND BLOCKS OF MATTER IN CLASS V PRIMARY SD NEGERI 168432 TEBING TINGGI
}

\author{
Hotmaida \\ Surel : ibuhotmaidasd@gmail.com
}

\begin{abstract}
The purpose of this research is to improve the activity and student learning outcomes in a cube of material and beam using in the method of inquiry. The subjects used in this study were students class V of SD Negeri 168432 Tebing Tinggi city, the number of 23 students. From the results of test that have been administered in the first cycle of action gained 14 students of the 23 students who have achieved mastery learning with classical completeness level equivalent to $30,43 \%$ or lower category. Because of the level of mastery learning classical is not reached, then procced to the second cycle. In the second cycle gained13 students from 23 students who have achieved mastery learning with classical completeness level equivalent to $56,52 \%$ or lower category. Because of the level of mastery learning classical is not reached, then procced to the three cycles. In the three cycles gained 19 students from 23 students who have achieved mastery learning with classical completeness level equivalent to 82,61\%, equivalent to a high category. In the three cycles has been no increase as expected.
\end{abstract}

Key words : Application of the method of inquiry, Activity, Learning outcomes

\begin{abstract}
ABSTRAK
Tujuan penelitian ini untuk meningkatkan aktivitas dan hasil belajar siswa pada materi kubus dan balok dengan menggunakan metode Inkuiri. Subjek yang digunakan dalam penelitian ini adalah siswa kelas V SD Negeri 168432 Kota Tebing Tinggi, dengan jumlah siswa 23 orang. Dari hasil test yang telah diberikan tindakan pada siklus I terdapat 7 siswa dari 23 siswa yang sudah mencapai ketuntasan belajar dengan tingkat ketuntasan klasikal 30,43\% atau setara dengan kategori rendah. Karena tingkat ketuntasan belajar klasikal belum tercapai, maka dilanjutjkan ke siklus II. Pada siklus II terdapat 13 siswa dari 23 siswa yang sudah mencapai ketuntasan belajar dengan tingkat ketuntasan klasikal 56,52\% atau setara dengan kategori rendah. Karena tingkat ketuntasan belajar klasikal belum tercapai, maka dilanjutjkan ke siklus III. Pada siklus III terdapat 19 siswa dari 23 siswa yang sudah mencapai ketuntasan belajar dengan tingkat ketuntasan klasikal 82,61\% atau setara dengan kategori tinggi. Pada siklus III ini sudah ada peningkatan sesuai yang diharapkan.
\end{abstract}

Kata Kunci : Penerapan metode inkuiri, aktivitas dan hasil belajar

\section{PENDAHULUAN}

Pendidikan pada dasarnya adalah usaha sadar yang menumbuh kembangkan potensi sumber daya manusia peserta didik dengan cara mendorong dan memfasilitasi kegiatan belajar mereka. Peningkatan mutu pendidikan disekolah didapat dari prestasi dan minat belajar siswa. Hasil belajar pada siswa merupakan 
sesuatu yang sangat penting dalam kehidupan, karena sepanjang aktivitasnya selalu berusaha untuk meraih hasil belajar menurut kemampuan masing-masing. SD Negeri 168432 tanggal 24 Juli 2017 menyatakan bahwa aktivitas dan hasil belajar siswa masih rendah. Hal ini terlihat dari nilai ulangan siswa pada materi kubus dan balok yang masih sebagian besar kurang mencapai Kriteria Ketuntasan Minimal (KKM) yaitu 75 yang diperoleh dari hasil ulangan harian pada materi kubus dan balok Tahun Pelajaran 2017/2018.

Dan ketika peneliti melihat cara guru mengajar, ternyata guru masih menggunakan cara langsug yang berpusat pada guru walaupun sekolah SD Negeri 168432 telah menggunakan Kurikulum Tingkat Satuan Pendidikan. Padahal dalam KTSP menuntut keaktifan siswa dalam proses belajar mengajar. Namun dalam kenyataannya yang lebih aktif adalah guru sedangkan siswanya pasif.

Guru harus terampil membangun jembatan penghubung antara pengalaman kongkrit dengan konsepkonsep matematika (Elvi Mailani, 2016 : Jurnal Handayani). Tetapi nyatanya, guru cenderung mendominasi pembelajaran, langsung memberikan rumus dann aturan matematika kepada siswanya tanpa memberitahukan asal muasal terbentuknya rumus matematika, memberikan contoh lalu latihan kepada siswa. Interaksi condong hanya satu arah, sesekali guru bertanya dan siswa menjawab, kemudian guru memberikan Pekerjaan Rumah (PR). Siswa dianggap objek yang hanya menerima yanng diberikan guru saja. Hal tersebut salah satu penyebab rendahnnya aktivtas dan hasil belajar siswa.

Sewaktu guru mengajar, tidak semua siswa memperhatikannya dengan sungguh-sungguh. Hanya sedikit yang belajar sungguhsungguh. Ada siswa yang bercerita dengann teman sebangkunya, ada juga siswa yang matanya seolah-olah memperhatikan pelajaran padahal pikirannya tidak terpusat kepelajaran. Ini terbukti ketika guru bertanya, dia hanya diam tidak merespon. Ada juga siswa mencoret-coret atau menggambar sesuatu yang tidak ada hubungannya dengan pelajaran matematika. Sebagian besar dari siswa menganggap pelajaran matematika merupakan pelajaran yang menakutkan dan sulit. Ditambah lagi paradigma yang telah tertanam pada mereka bahwa guru matematika mengerikan dan kejam. Siswa cenderung pasif dalam pelajaran matematika.

Berdasarkan latar belakang masalah diatas maka dapat diidentifikasi masalah yang timbul sebagai berikut:

a. Kurangnya aktivitas belajar siswa dalam pelajaran matematika.

b. Banyaknya kesalahan dalam menyelesaikan soal kubus dan balok

c. Sewaktu guru mengajar, tidak semua siswa memperhatikannya dengan sungguh-sungguh 
d. Guru lebih aktif dan siswa cenderung pasif

e. Metode pembelajaran yang digunakan guru masih kurang tepat

f. Rendahnya hasil belajar siswa pada materi pokok Kubus dan Balok

Mengingat luasnya cakupan masalah dan keterbatasan peneliti, maka masalah yang disebutkan dalam identifikasi masalah di atas dibatasi pada:

a. Kurangnya aktivitas dan rendahnya hasil belajar siswa dalam pelajaran matematika

b. Upaya meningkatkan aktivitas dan hasil belajar siswa dengan menggunakan

metode pembelajaran inkuiri

\section{METODE PENELITIAN}

Jenis penelitian ini adalah penelitian tindakan kelas (Classroom Action Reserach) dimana penelitian ini dilaksanakan di dalam kelas ketika pembelajaran berlangsung. Wijaya (2013:39) menjelaskan bahwa "PTK dilakukan dengan tujuan untuk memperbaiki atau meningkatkan kualitas pembelajaran. Prosedur pelaksanaan PTK dapat dilihat pada gambar rangkaian kegiatan dari setiap siklus berikut:

\section{Gambar Proses Pelaksanaan Tindakan Kelas}

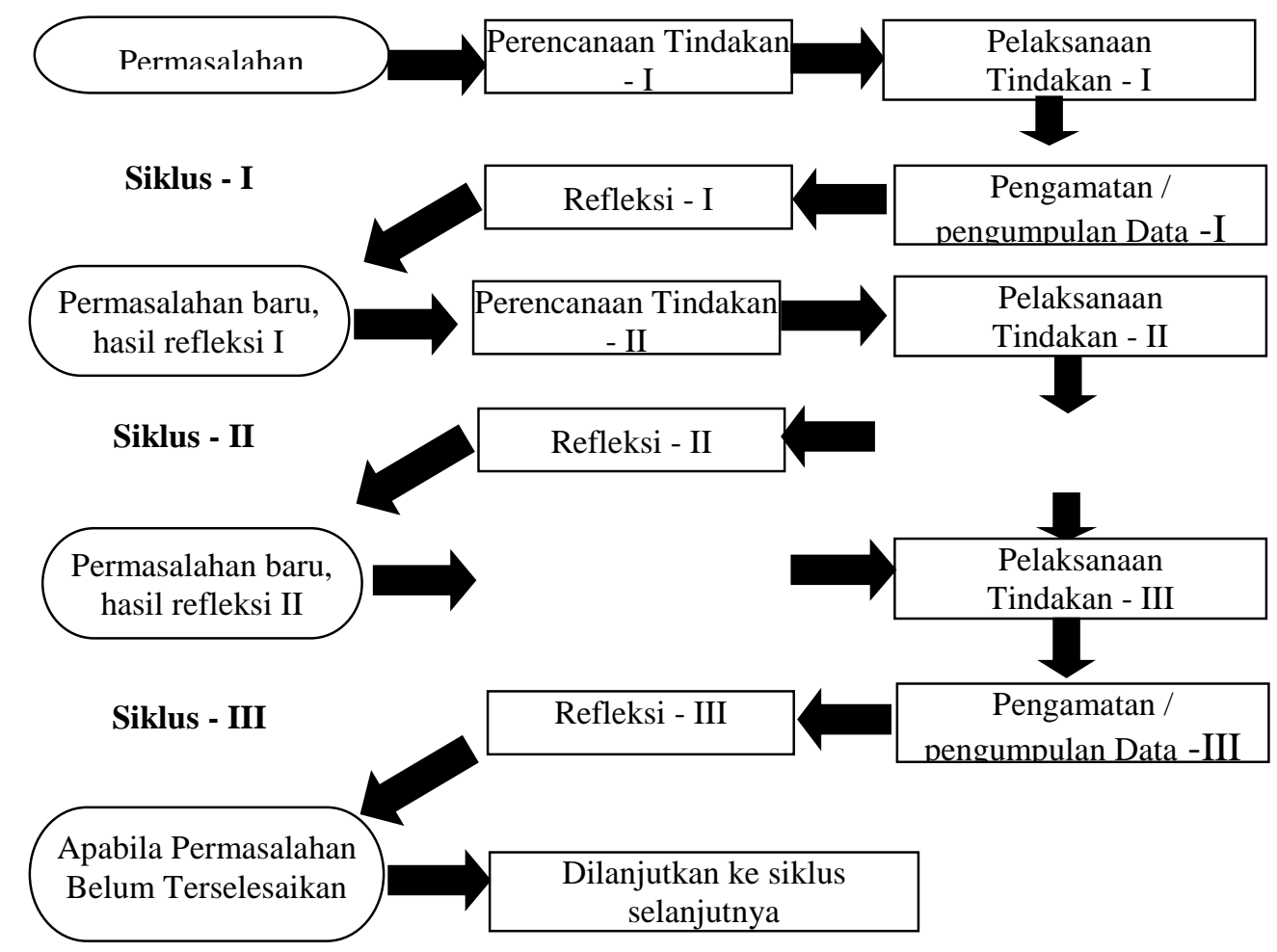


Prosedur pelaksanaan PTK yang meliputi penetapan fokus permasalahan, perencanaan tindakan, pelaksanaan tindakan yang diikuti dengan kegiatan observasi , interpretasi, dan analisis, serta refleksi. Apabila diperlukan, pada tahap selanjutnya disusun rencana tindak lanjut. Upaya tersebut dilakukan secara berdaur membentuk suatu siklus. Seperti yang dikemukakan Wijaya, dkk (2013:59) Langkah-langkah pokok yang ditempuh pada siklus pertama dan siklus-siklus berikutnya adalah sebagai berikut: "1) Penetapan fokus permasalahan, 2)

Perencanaan tindakan, 3)

Pelaksanaan tindakan 4)

Pengumpulan data /Pengamatan 5) Refleksi.

Pelaksanaan penelitian ini dimulai dengan siklus pertama. Apabila diketahui letak keberhasilan dan letak ketidak keberhasilan tindakan pada siklus pertama, maka penulis menentukan rancangan untuk siklus kedua, dan begitu seterusnya sampai peningkatan yang diinginkan tercapai. Dalam hal ini penulis merencanakan atau melaksanakan dua siklus, pemaparan dua siklus tersebut dapat dilihat pada rancangn penelitianberikut ini, yaitu:

Berdasarkan hasil ulangan harian siswa yang sudah diuraikan dalam latar belakang masalah sebelumnya, diperoleh suatu masalah dimana peneliti mendapatkan 26,09\% (6 siswa) yang memenuhi KKM dan $73,91 \%$ (17 siswa) yang di bawah KKM.
Dari soal yang diberikan, diidentifikasi masalah-masalah yang dihadapi siswa secara umum pada materi kubus dan balok, diantaranya:

a. Beberapa siswa kurang mampu membedakan benda yang termasuk kedalam contoh kubus dan benda yang termasuk ke dalam contoh balok

b. Untuk mencari volume antara kubus dan balok, sebahagian siswa masih bingung untuk menggunakan rumus yang mana

c. Siswa kurang mampu memahami unsur-unsur yang terdpat pada kubus dan balok

Pada tahap ini peneliti
melaksanakan kegiatan belajar mengajar dngan menggunakan metode pembelajaran inkuiri. Adapun hal-hal yang dirancang adalah sebagai berikut :

a. Membuat Rencana Pelaksanaan Pembelajaran (RPP)dengan menggunakan metode pembelajaran inkuiri pada materi kubus dan balok

b. Mempersiapkan sarana pendukung pembelajaran yang mendukung pelaksanaan tindakan, yaitu : lembar aktivitas siswa (LAS), buku matematika kelas V sebagai bahanajar untuk siswa, spidol, dan lembar observasi.

c. Mempersiapkan instrumen penelitian, yaitu tes hasil belajar I dalam bentuk uraian dengan jumlah soal sebanyak 5 butir dan lembar observasi aktivitas siswa. 
Setelah

dilakukan

rencanatindakan siklus I, maka selanjutnya dilakukan dilakukan pelaksanaan tindakan siklus I sebagai berikut

a. Melaksanakan pembelajaran sesuai rencana pembelajaran yang telah dibuat sebelumnya.

b. Memberikan bebrapa contoh bentuk kubus dan balokdaan menjelaskan mengenai unsurunsur kubus dan balok

c. Bertanya kepada siswa mengenai unsur-unsur dan pada kubus dan balok yang kurang dipahami, dan menjelaskannya kembali dengan singkat.

d. Memberi tes kepada setiap siswa untuk mengetahui hasil belajar siswa

Observasi dilakukan bersamaan dengan tahap pelaksanaan tindakan siklus I, yaitu kegiatan belajar mengajar berlangsung. Observasi dilakukan oleh guru mata pelajaran terhadap hal-hal yang terjadi pada saat pemberian tindakan dengan tujuan agar diketahui apakah kondisi belajar sesuai dengan rencana pelaksanaan pembelajaran. Pada tahap ini peniliti mengumpulkan dan menganalisis catatan yang diperoleh selama observasi dan hasil analisis data memperlihatkan keberhasilan dan kegagalan dari tindakan yang telah dilaksanakan untuk mengatasi kesulitan belajar dan tingkat ketuntasan belajar belum tercapai, maka dilanjutkan pada siklus II. Untuk itu guru merancang suatu perbaikan atau pengembangan dari tindakan kelas.

Apabila siklus 1 belum meningkatkan aktivitas dan hasil belajar matematika siswa, maka perlu dilaksanakan siklus II. Pada siklus II diadakan kembali permasalahan, perencanaan, pelaksanaan dan pengamatan berdasarkan perbaikan dari siklus I, kemudian refleksi untuk membuat kesimpulan dari hasil yang didapat.

Apabila siklus II belum meningkatkan aktivitas dan hasil belajar matematika siswa, maka perlu dilaksanakan siklus III. Pada siklus III diadakan kembali permasalahan, perencanaan, pelaksanaan, dan pengamatan berdasarkan perbaikan siklus II, kemudian refleksi untuk membuat kesimpulan dari hasil yang didapat.Bidang studi matematika membantu untuk mengobservaasi selama kegiatan belajar mengajar berlangsung.

Subjek penelitian ini adalah adalah siswa kelas V SD Negeri 168432 Kota Tebing Tinggi. Dalam penelitian ini dipilih satu kelas dari dua kelas yang ada, yaitu kelas V yang siswanya berjumlah 23 orang.

Objek penelitian ini adalah untuk meningkatkan aktivitas dan hasil belajar dengan menerapkan metode pembelajaran inkuiri pada materi pokok kubus dan balok bagi siswa kelas V SD Negeri 168432 Kota Tebing Tinggi.

Dalam penelitian ini yang menjadi variabel adalah aktivitas dan hasil belajar matematika siswa dalam pembelajaran kubus dan balok kelas 
V SD Negeri 168432 Kota Tebing Tinggi. Adapun indikator dalam penelitian ini adalah skor hasil tes dan hasil observasi untuk aktivitas yang diperoleh siswa dalam mengikuti pelajaran dengan melalui metode pembelajaran inkuiri.

Dalam penelitian ini instrumen yang digunakan berupa tes yang akan dilakukan pada setiap akhir siklus dan lembar Observasi aktivitas (siswa dan guru) yang akan dilakukan pada setiap siklus.

Tes digunakan untuk mengetahui peningkatan hasil belajar siswa meningkat dalam materi kubus dan balok. Dalam penelitian ini, tes hasil belajar yang digunakan berupa tes tertulis berbentuk essay. Tes diberikan 3 kali, yaitu pada setiap akhir siklus. Tes terdiri dari 5 butir soal untuk siklus I, 5 butir soal untuk siklus II, dan 5 butir soal untuk siklus III.

\section{HASIL PENELITIAN DAN PEMBAHASAN}

Pada bagian ini peneliti akan membahas tentang hasil penelitian yang telah dilakukan di kelas V SD Negeri 168432 Hasil penelitian ini akan diuraikan berdasarkan hasil yang telah dilakukan dalamm 3 tahapan yang berlangsung dalam 3 siklus. Di bawah ini akan diuraikan hasil penelitian yang telah berlangsung berdasarkan siklus dan tahapan yang dilakukan.

Siklus 1 dilaksanakan dalam dua pertemuan, pertemuan pertama pada hari senin tanggal 06 Agustus 2017 dan pertemuan kedua pada hari kamis tanggal 19 Agustus 2017.

Tabel Hasil Observasi Pada Siklus I

\begin{tabular}{|c|c|c|c|c|c|}
\hline $\mathrm{Nc}$ & Aspek yang diamati & Jumlah & Persentase & Baik & Cukup \\
\hline \multicolumn{6}{|c|}{ Kurang } \\
\hline 1 & $\begin{array}{l}\text { Memperhatikan dan } \\
\text { Mendengarkan } \\
\text { Penjelasan guru }\end{array}$ & 16 & $69,57 \%$ & & $\sqrt{ }$ \\
\hline 2 & $\begin{array}{l}\text { Mengajukan } \\
\text { Pertanyaan }\end{array}$ & 12 & $52,17 \%$ & & $\sqrt{ }$ \\
\hline 3 & $\begin{array}{l}\text { Mengemukakan } \\
\sqrt{ } \\
\text { Ide/pendapat }\end{array}$ & 5 & $21,73 \%$ & & \\
\hline 4 & $\begin{array}{l}\text { Keaktifan dalam } \\
\sqrt{ } \\
\text { Kelompok }\end{array}$ & 9 & $39,13 \%$ & & \\
\hline 5 & Menjawab pertanyaan & 6 & $26,07 \%$ & & \\
\hline 6 & $\begin{array}{l}\text { Guru } \\
\text { Menyelesaikan } \\
\sqrt{ }\end{array}$ & 3 & $13,04 \%$ & & \\
\hline
\end{tabular}


Persoalan

\begin{tabular}{|c|c|c|}
\hline$\underset{\sqrt{ }}{\text { Mencatat hasil diskusi }}$ & 11 & $47,83 \%$ \\
\hline $\begin{array}{l}\text { Menyimpulkan } \\
\text { pelajaran }\end{array}$ & 7 & $30,43 \%$ \\
\hline
\end{tabular}

Dari tabel diatas bahwa pada pengamatan kedua pada aktivitas siswa memperoleh persentase sebesar $37,5 \%$. Setelah pemberian tindakan dilaksanakan maka diberikan evaluasi akhir pembelajaran yaitu tes yang terdiri dari 5 soal uraian tes kepada siswa. Hal ini bertujuan untuk mengetahui keberhasilan tindakan yang diberikan.
Siklus II dilaksanakan dalam II pertemuan, pertemuan pertama pada hari senin tanggal 19 Agustus 2017 dan pertemuan kedua pada hari kamis tanggal 24 Agutus 2017, Pembahasan materi yaitu mengenai jaring-jaring kubus dan balok. Tahapan-tahapan yang dilakukan oleh peneliti selama proses pembelajaran siklus II adalah sebagai berikut :

Tabel Hasil Observasi Pada Siklus II

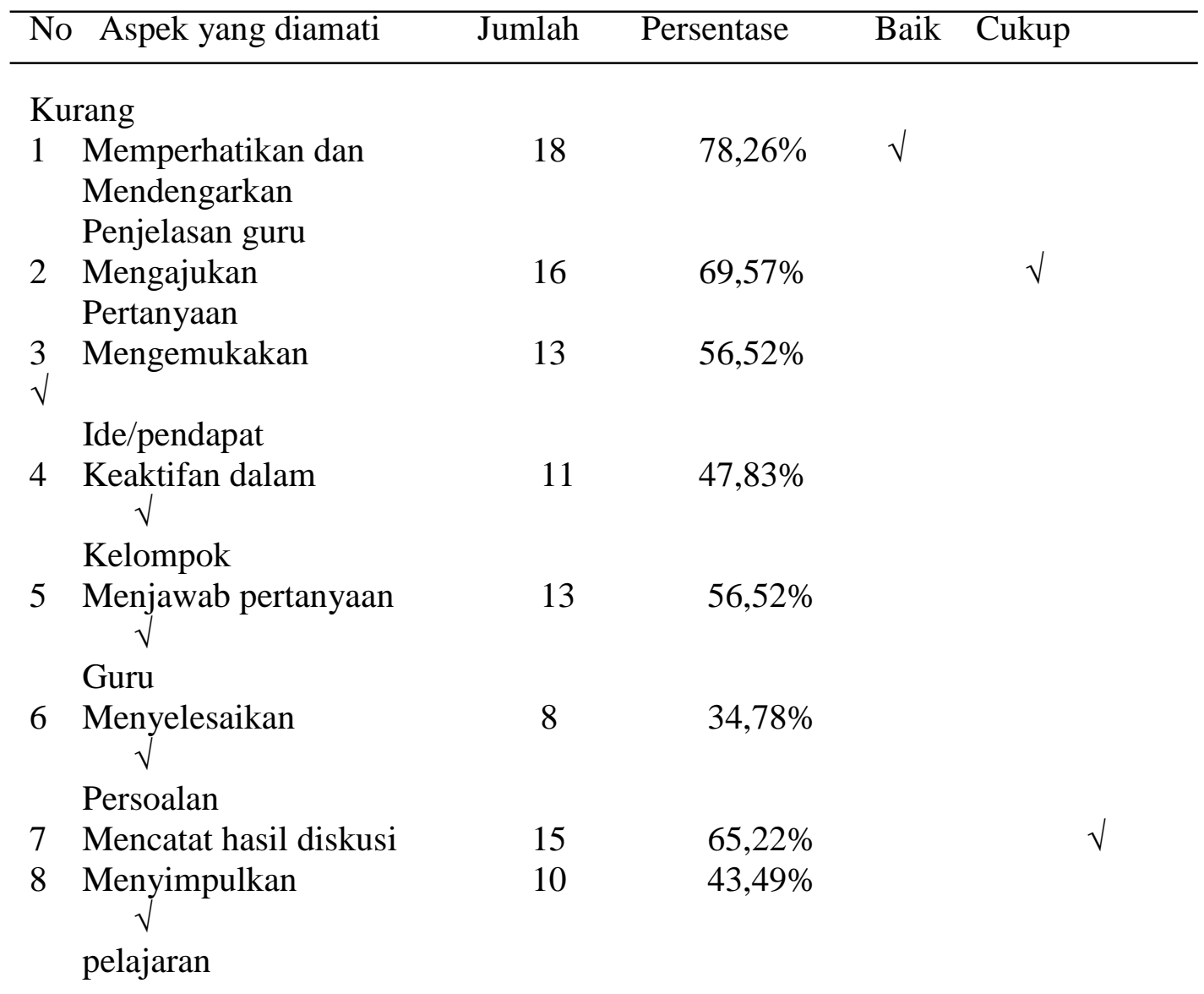


Dari tabel diatas bahwa pada pengamatan kedua pada aktivitas siswa memperoleh persentase sebesar $56,52 \%$. Setelah pemberian tindakan dilaksanakan maka diberikan evaluasi akhir pembelajaran yaitu tes yang terdiri dari 5 soal uraian tes kepada siswa. Hal ini bertujuan untuk mengetahui keberhasilan tindakan yang diberikan.

Siklus II dilaksanakan dalam II pertemuan, pertemuan pertama pada hari senin tanggal mei 2017 dan pertemuan kedua pada hari kamis tanggal 09 September 2017 Pembahasan materi yaitu mengenai jaring-jaring kubus dan balok.

Tabel Hasil Observasi Pada Siklus III

\begin{tabular}{|c|c|c|c|c|c|}
\hline & Aspek yang diamati & Jumlah & Persentase & Baik & Cukup \\
\hline \multicolumn{6}{|c|}{ Kurang } \\
\hline 1 & $\begin{array}{l}\text { Memperhatikan dan } \\
\text { Mendengarkan } \\
\text { Penjelasan guru }\end{array}$ & 21 & $91,30 \%$ & $\sqrt{ }$ & \\
\hline 2 & $\begin{array}{l}\text { Mengajukan } \\
\text { Pertanyaan }\end{array}$ & 18 & $73,91 \%$ & $\sqrt{ }$ & \\
\hline 3 & $\begin{array}{l}\text { Mengemukakan } \\
\text { Ide/pendapat }\end{array}$ & 16 & $65,22 \%$ & & $\sqrt{ }$ \\
\hline 4 & $\begin{array}{l}\text { Keaktifan dalam } \\
\text { Kelompok }\end{array}$ & 17 & $69,57 \%$ & & $\sqrt{ }$ \\
\hline 5 & $\begin{array}{l}\text { Menjawab pertanyaan } \\
\text { Guru }\end{array}$ & 17 & $69,57 \%$ & & $\sqrt{ }$ \\
\hline 6 & $\begin{array}{l}\text { Menyelesaikan } \\
\text { Persoalan }\end{array}$ & 22 & $95,65 \%$ & $\sqrt{ }$ & \\
\hline 7 & Mencatat hasil diskusi & 18 & $78,26 \%$ & $\sqrt{ }$ & \\
\hline 8 & $\begin{array}{l}\text { Menyimpulkan } \\
\text { pelajaran }\end{array}$ & 10 & $86,96 \%$ & $\sqrt{ }$ & \\
\hline
\end{tabular}

Dari tabel diatas bahwa pada pengamatan ketiga pada aktivitas siswa memperoleh persentase sebesar $80,9 \%$. Setelah pemberian tindakan dilaksanakan maka diberikan evaluasi akhir pembelajaran yaitu tes yang terdiri dari 5 soal uraian tes kepada siswa.

Tabel Perbandingan Hasil Tes Siklus I, II, dan III

\begin{tabular}{|l|l|l|l|}
\hline Siklus & Siswa & Persentase Ketuntasan Belajar & Kategori \\
\hline I & 23 & $30,43 \%$ & Kurang \\
\hline
\end{tabular}




\begin{tabular}{|l|l|l|l|}
\hline II & 23 & $56,52 \%$ & Kurang \\
\hline III & 23 & $82,61 \%$ & Baik \\
\hline
\end{tabular}

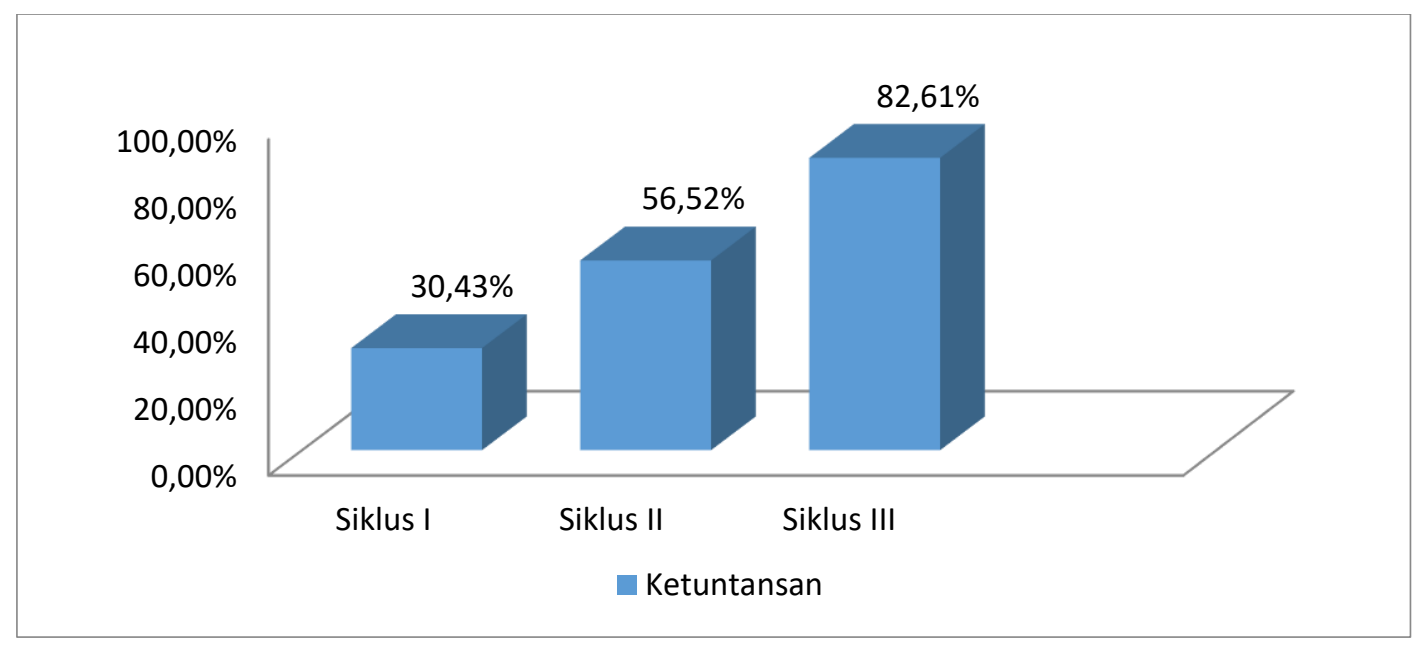

\section{Grafik perbandingan hasil tes belajar siswa siklus I, II dan III}

\section{SIMPULAN}

Berdasarkan hasil penelitian yang telah diuaraikan pada bab IV dapat diambil kesimpulan adalah sebagai berikut :

a. Dengan menggunakan metode pembelajaran inkuiri dapat meningkatkan aktivitas belajar siswa. Hal ini dapat dilihat dari persentase yang diperoleh dari siklus I, II, dan III. Hasil observasi pada siklus I diperoleh persentase aktivitas, yaitu $37,5 \%$. Hasil observasi aktivitas siswa pada siklus II terjadi peningkatan sebesar $19,02 \%$ sehingga diperoleh persentase pada siklus II sebesar 56,52\%.Dan pada siklus ke III terjadi peningkatan 24,38\%, sehingga diperoleh persentase pada siklus III sebesar $80,9 \%$. b. Dengan menggunakan metode pembelajaran inkuiri dapat meningkatkan hasil belajar siswa pada materi kubus dan balok. Hal ini dapat dibuktikan dari hasil tes yang telah diberikan mulai ndari siklus I, II, sampai siklus III. Dari siklus I diperoleh persentase ketuntasan sebesar 30,43\%, sedangkan pada siklus II diperoleh persentase ketuntasan sebesar $56,52 \%$, dan pada siklus ke III diperoleh persentase ketuntasan sebesar 82,61dan telah mencapai target ketuntasan secara klasikal. Dari data tersebut dapat disimpulkan bahwa terjadi peningkatan sebesar.... 
DAFTAR RUJUKAN

Arikunto. 2012. Dasar- dasar Evaluasi Pendidikan. Jakarta: PT. Bumi Aksara.

Istarani. 2012. 58 Model Pembelajaran Inovatif. Medan: Media Persada.

Mailani, E. 2016. Upaya Meningkatkan Hasil Belajar Matematika Pada Materi Pecahan Melalui Permainan Monopoli Pecahan. JURNAL HANDAYANI PGSD FIP UNIMED, 4(1).

Sardiman, A. M. 2009. Interaksi dan Motivasi Belajar Mengajar. Jakarta: PT. Rajagrafindo Persada.

Shoimin, Aris. 2014. 68 Model Pembelajaran Inovatif dalam Kurikulum 2013. Yogyakarta: Ar-ruzz Media.

Slameto. 2013. Belajar dan Faktorfaktor yang Mempengaruhinya, Jakarta : Rineka Cipta.

Sudjana, Dr. Nana. 2010. Penilaian Hasil Proses Belajar Mengajar. Bandung: PT. Remaja Rosdakarya.

Sanjaya. 2011. Strategi Pembelajaran Berorientasi Standar Proses Pendidikan. Bandung: Kencana.

Sukino, dkk. 2006. Matematika SMP jilid 2 untuk kelas VIII. Jakarta : Erlangga

Trianto. 2011. Mendesain Model Pembelajaran InovatifProgresif: Konsep, Landasan, dan Implementasinya pada Kurikulum Tingkat Satuan
Pendidikan (KTSP). Surabaya: Kencana.

Wijaya, H. Candra, dkk, 2013. Penelitian Tindakan Kelas. Bandung: Cita Pustaka Media Perintis. 